\title{
FROM WANDERERS TO WORKERS: A SURVEY OF FEDERAL AND STATE EMPLOYMENT RIGHTS OF THE MENTALLY ILL
}

\author{
I

\section{INTRODUCTION}

In the last decade, the Federal Government and state legislatures have enacted a plethora of statutes designed to aid and protect the mentally ill in their quest to become part of America's work force. These statutes are one result of the changes in society's attitudes toward the mentally ill which have been occurring since this country was founded over 200 years ago.

The early American colonists brought from Europe a belief that mental illness was chiefly a form of demoniacal possession, for which the most common methods of treatment were various forms of torture. ${ }^{1}$ Mentally ill persons who escaped characterization as witches were classified either as "violent," in which case they were thrown into prisons and dungeons, or as "harmless," which permitted them to roam the countryside aimlessly. ${ }^{2}$ Shakespeare described these wandering "Toms o' Bedlam" as follows:

[P]oor Tom, that eats the swimming frog, the toad, the tadpole, the wall newt and the water newt, that in the fury of his heart, when the foul fiend rages, eats cow-dung for sallets, swallows the old rat and the ditch dog, drinks the green mantle of the slimy pool; who is whipt from tything to tything, and stocked, punished, and imprisoned . . . 3

Gradually mentally ill persons began to find themselves in safer, if not ideal, quarters. The Pennsylvania Hospital, in 1752, was the first American institution to admit mental patients for the purpose of curative treatment. ${ }^{4}$ While this was quite a stride in the cure and treatment of mentally ill persons, therapeutic methods were primitive, and the hospitals were abominably maintained. ${ }^{5}$ Charles Dickens, who said many wonderful things about his celebrated trip to America in the mid-19th century, was very distressed at what he saw on a visit to a New York lunatic asylum. Dickens wrote,

I cannot say that I derived much comfort from the inspection of this charity. . . I saw nothing of that salutary system which had impressed me so favorably elsewhere; and every-

Copyright $(1983$ by Law and Contemporary Problems

1. A. Deutsch, The Mentally Ill In America 24 (1937).

2. Id. at 23.

3. W. Shakespeare, King Lear act III, scene IV.

4. A. Deutsch, supra note 1 , at 60 .

5. Id. at 61 . 
thing had a lounging, listless, madhouse air which was very painful. The moping idiot, cowering down with long, dishevelled hair; the gibbering maniac, with his hideous laugh and pointed finger; the vacant eye, the fierce wild face, the gloomy picking of the hands and lips with munching of the nails: they were all, without disguise, in naked ugliness and horror. ${ }^{6}$

Tremendous advances in therapeutic equipment and techniques have been made during the 20th century. ${ }^{7}$ Sigmund Freud's teachings influenced various schools of psychotherapy. ${ }^{8}$ Additionally, techniques such as occupational therapy and hydrotherapy assumed important roles in the rehabilitation of the mentally ill. ${ }^{9}$ As these treatment advances were being made there was an important attitudinal change toward the mentally ill which was reflected in the replacement of the custodial ideal by a curative approach to their treatment. ${ }^{10}$

This article surveys the state and federal legislation which adopts this curative approach. These statutes are aimed at preventing discrimination, and in some cases at requiring affirmative action, in the hiring of mentally ill individuals. Although there has been a surprising lack of litigation over the application and interpretation of these various statutes, they raise complex issues which often reflect a progressive and optimistic attitude toward the ability of mentally ill individuals to become integrated members of society. These issues are worth examining, if only as another chapter in the relationship between the mentally ill and the society of which they have only recently become a part.

\section{II}

\section{Employment Statutes Prohibiting Discrimination Against the Mentally Ill: AN Overview}

There are several avenues for instituting employment discrimination suits on the basis of mental illness. " The primary federal tool for these suits is the 1973 Rehabilitation Act. ${ }^{12}$ Twenty-nine states and the District of Columbia have also enacted statutes protecting the mentally ill from discrimination in employment. ${ }^{13}$

\section{A. 1973 Rehabilitation Act}

Two sections of the 1973 Rehabilitation Act deal with the mentally ill: sections 504 and 503 . Section 504 is a general antidiscrimination statute prohibiting discrimination against an otherwise qualified handicapped person in programs

6. 1 C. Dickens, American Notes for General Circulation 221-23 (1842).

7. A. DeutsCh, supra note 1 , at 443.

8. Id.

9. Id.

10. Id.

11. Other avenues not discussed here include due process, equal protection, 42 U.S.C. $\$ 1983$, and arbitration. For an example of due process, see Spencer v. Toussaint, 408 F. Supp. 1067 (E.D. Mich. 1976). For an example of equal protection and the use of $\$ 1983$, see Gurmankin v. Costanzo, 411 F. Supp. 982 (E.D. Pa. 1976), affd, 556 F.2d 184 (3d Cir. 1977), cert. denied, 450 U.S. 923 (1981). For more on arbitration, see Marmo, The Arbitration of Mental Illiness Cases, 31 LAB. L.J. 403 (1980), In re Appleton Elec. Co., 76 Lab. Arb. (BNA) 167 (1981) (Roomkin, Arb.) and $I n$ re City of Fenton, 76 Lab. Arb. (BNA) 355 (1981) (Roumell, Arb.).

12. 29 U.S.C. $\S 701-794 a$ (1976 \& Supp. IV 1980).

13. See infra note 25 . 
receiving federal assistance. ${ }^{14}$ The section applies to recruiting, hiring, compensation, job assignments, sick leave, fringe benefits, and "[a]ny other term, condition or privilege of employment."15 Section 503 of the Act applies to federal contractors with contracts in excess of $\$ 2500$ and requires the contractor to take affirmative action to employ qualified handicapped individuals. ${ }^{16}$

As with any federal statute, there are regulations governing the interpretation and application of each section. ${ }^{17}$ Regulations under both sections restrict the use of preemployment inquiries. To comply with section 503, the employer must review all "mental job qualification requirements to insure that, to the extent qualification requirements tend to screen out qualified handicapped individuals, they are job related and are consistent with business necessity and the safe performance of the job."18

Section 504 regulations also require that any employment criteria used by a recipient of federal assistance be job related, and that there be no alternative criteria that screen out fewer handicapped persons. ${ }^{19}$ The regulations provide that a recipient may not ask an applicant "whether the applicant is a handicapped person or as to the nature or severity of a handicap. A recipient may, however, make preemployment inquiry into an applicant's ability to perform job-related functions." 20 The latter portion of the regulation has been interpreted to mean that an employer may not ask an applicant if he has ever experienced mental problems. The applicant, however, can be asked if he is capable of handling certain emotionally difficult situations. ${ }^{21}$

Regulations under both sections allow preemployment medical examinations as long as the results are used only in accordance with sections 503 and 504 and all employees are made to submit to such examinations. ${ }^{22}$ An employer is required to make reasonable accommodation for its handicapped employees under both sections unless such accommodation would "impose undue hardship on the operation of its program." 23 In deciding what is undue hardship, factors to be considered

14. 29 U.S.C. $\$ 794$ (1976 \& Supp. IV 1980).

15. See, e.g., 45 C.F.R. $\$ 84.11$ (b) (1981); 34 C.F.R. $\$ 104.11(\mathrm{~b})$ (1981).

16. 29 U.S.C. $\$ 793$ (1976 \& Supp. IV 1980).

17. Regulations under section 504 are promulgated by each department distributing funds for federal programs, see 34 C.F.R. $\S \S 104.1-104.61$ (1981) (Dep't of Ed.); 45 C.F.R. $\$ \S 84.1-84.61$ (1981) (Dep't of Health \& Human Services), while the Office of Federal Contract Compliance Programs (OFCCP) of the Department of Labor issues regulations under section 503, see 41 C.F.R. $\$ \S 60-741.1$ - .54 (1981).

18. 41 C.F.R. $\$ 60-741.6(c)$ (1) (1981).

19. 45 C.F.R. $\$ 84.13$ (a) (1981); 34 C.F.R. $\S 104.13$ (a) (1981).

20. 45 C.F.R. $\$ 84.14$ (a) (1981); 34 C.F.R. $\$ 104.14$ (a) (1981).

21. Doe v. Syracuse School District, 508 F. Supp. 333, 337 (N.D.N.Y. 1981). In Doe, the plaintiff applied for a job as a teacher's assistant or substitute teacher. He was asked to complete a vital statistics form which asked whether he had ever suffered a nervous breakdown or received psychiatric treatment. The plaintiff responded affirmatively and was denied a job on this ground even though he was examined and found mentally qualified for the job. The school district admitted that past history of mental problems was not an indication of the plaintiff's present fitness for the job. The court found that the defendant had violated section 504 through its preemployment inquiries and granted summary judgment for the plaintiff.

22. 45 C.F.R. $\$ 84.14$ (c) (1981); 34 C.F.R. $\$ 104.14$ (c) (1981); 41 C.F.R. $\$ 60-741.6$ (c) (3) (1981)

23. 45 C.F.R. $\$ 84.12(a)$ (1981); 34 C.F.R. $\$ 104.12(a)$ (1981). See 41 C.F.R. $\S 60-741.6(d)$ (1981). 
include size of the program, type of operation, and nature and cost of accommodation. ${ }^{24}$

\section{B. State Statutes}

Only twenty-nine states and the District of Columbia provide any statutory relief to the victim of employment discrimination on the basis of mental handicap. ${ }^{25}$ Although the language differs somewhat from state to state, the statutes are essentially similar, providing that an employer shall not base hiring, promotion, or discharge decisions on an employee's or an applicant's mental handicap. Furthermore, an employer may not discriminate against any mentally handicapped person with respect to compensation or any other terms, conditions, or privileges of employment. Some of the state statutes also restrict the use of preemployment inquiries concerning mental illness. ${ }^{26}$

Thirteen of the statutes make some reference, either direct or indirect, to affirmative action programs. ${ }^{27}$ Only four of these statutes require the development of affirmative action plans, ${ }^{28}$ and their scope is limited because they apply only to limited groups of employers. Under the District of Columbia statute, an affirmative action plan "is any plan devised to effectuate remedial or corrective action in response to past discriminatory practices . . . and may also include those plans devised to provide preferential treatment for a class or classes of persons, which preferential treatment by class would otherwise be prohibited." 29 The District of

24. 45 C.F.R. $\$ 84.12$ (c) (1981); 34 C.F.R. $\S 104.12(\mathrm{c})(1981)$

25. Conn. Gen. Stat. $\S 46 a-60(a)(1)$, (2) (West Supp. 1982); D.C. Code AnN. \$1-2512 (1981); Fla. Stat. ANn. § 23.167(1)(a) (West Supp. 1982); GA. Code AnN. § 66-504(a) (Supp. 1981); Ill. AnN. STAT. ch. 68, § 2-102(A) (Smith-Hurd Supp. 1982-83); IND. Code ANN. § 22-9-1-2 (Burns 1976 \& Supp. 1982); IOWA Code § 601A.6(1) (1975); ME. Rev. STAT. ANN. tit. 5, §4572 (1979); MD. ANN. CodE art. 49B, $\S 16(a)$, (d) (1979); Mass. Ann. Laws ch. 149, $\$ 24 \mathrm{~K}$ (Michie/Law. Co-op. 1976); Mich. Comp. Laws ANN. §37.1202 (Supp. 1982-83); MinN. STAT. § 363.03(1)(2) (Supp. 1981); MoNT. Code ANN. § 49-2303(a) (1981); Neb. Rev. Stat. § 48-1104 (1978); N.H. ReV. Stat. ANN. § 354-A:8(I)(Supp. 1981); N.J. STAT. ANN. § 10:5-4.1 (West Supp. 1982-83); N.M. STAT. ANN. § 28-1-7(A), (C) (1978); N.Y. Exec. LAW $\S 296(1)$, (1-a) (McKinney 1982); N.C. Gen STAT. \$128-15.3 (1981); Ohio Rev. Code ANN. $\$ 4112.02$ (A), (D) (Page Supp. 1982); OR. Rev. STAT. $\$ 659.425$ (1)(a) (1981); PA. Stat. AnN. tit. 43, $\S$ 955(a) (Purdon Supp. 1965-81); R.I. GeN. Laws $\S \S 28-5-5.3,28-5-6,28-5-7(A)$ (1979 \& Supp. 1981); TenN. Code AnN. § 8-50-103(a) (1980); Tex. Hum. Res. Code AnN. §121.003(f) (Vernon 1980); UTAH Code ANN. \$34-35-6(1) (a), (f) (Supp. 1981); Vt. Stat. AnN. tit. 21, § 495(a)(1) (Supp. 1982); WaSh. REV. Code ANN. $\$ 49.60 .180(1)$, (2) (Supp. 1982); W. VA. Code $\S 5-11-9$ (a) (Supp. 1982); Wis. STAT. ANN. $\S 111.325$ (West 1974). Illinois also has a constitutional provision requiring that "persons with a physical or mental handicap . . . shall be free from discrimination unrelated to ability in the hiring and promotion practices of any employer." ILL. CONST. art. I, § 19.

26. Me. Rev. Stat. AnN. tit. 5, § 4572(D) (1979); Mich. Comp. Laws AnN. § 37.1206(2)(a) (Supp. 1982-83); Minn. Stat. § 363.03(4)(a) (Supp. 1981); Mont. Code AnN. § 49-2-305(c) (1981); N.M. STAT. ANN. §28-1-7(D) (1978); N.Y. EXEC. LAW § 296(1)(d) (McKinney 1982); OHio Rev. Code ANN. $\S 4112.02(E)$ (Page Supp. 1982); PA. STat. AnN. tit. 43, § 955(b)(1) (Purdon Supp. 1965-81); R.I. GeN. LaWs §28-5-7(D) (1979 \& Supp. 1981); Utah CODE ANN. § 34-35-6(1)(d) (Supp. 1981); Wash. Rev. CODE ANN. § 49.60.180(4) (Supp. 1982).

27. D.C. Code AnN. § 1-2524(a) (1981); Ga. Code AnN. § 66-504(a) (Supp. 1981); Ill. AnN. STAT. ch. 68, § 2-105 (Smith-Hurd Supp. 1982-83); IND. Code ANN. § 22-9-3 (Burns Supp. 1982); MD. ANN. Code art. 49B, § 16(h) (1979); Mich. Comp. Laws Ann. § 37.1208 (Supp. 1982-83); Minn. Stat. $\S 363.073$ (1) (Supp. 1981); MONT. CoDe ANN. § 49-2-403 (1981); Neb. Rev. Stat. § 48-1113 (1978); Or. Rev. Stat. $\$ 659.100$ (1981); Pa. Stat. AnN. tit. 43, §955(b) (Purdon Supp. 1965-81); R.I. Gen. Laws $\S 28-5-22$ (1979); UTAH CoDE ANN. § 34-35-6(2)(e) (Supp. 1981)

28. D.C. Code AnN. § 1-2524(b) (1981); Ill. AnN. STat. ch. 68, § 2-105 (Smith-Hurd Supp. $1982-$ 83); IND. Code ANN. § 22-9-3-2 (Burns Supp. 1982); MinN. STAT. § 363.073(1) (Supp. 1981).

29. D.C. CoDE ANN. § 1-2524(a) (1981). 
Columbia statute requires all banks and savings and loan associations to implement such a plan, which is subject to approval by the District of Columbia Office of Human Rights. ${ }^{30}$ Similar plans by other employers are voluntary but are enforceable if approved by the Office of Human Rights. ${ }^{31}$ Illinois has a more demanding affirmative action statute than the District of Columbia, but its coverage does not extend to private employers. ${ }^{32}$ Under the Illinois statute, every state agency must establish a continuing affirmative action plan "designed to promote equal opportunity in every aspect of agency personnel policy and practice."'33 The agency must submit reports to the Department of Human Rights indicating: the number, percentage, and average salary of handicapped individuals employed by the agency; the positions in which the percentage of handicapped people employed is less than four-fifths of the percentage of handicapped people in the state work force as a whole; and a description of the methods and goals the agency has planned for increasing the percentage of handicapped individuals employed by the agency. ${ }^{34}$ If an agency has 1000 or more employees, it must also appoint a full-time equal employment opportunity officer to plan affirmative action programs, work on recruitment programs for the agency, inform aggrieved individuals concerning their statutory rights, and give general employment advice to the agency. ${ }^{35}$

Another approach to affirmative action programs is taken by Oregon ${ }^{36}$ and Michigan. ${ }^{37}$ Their statutes encourage public and private employers to use voluntary, preferential hiring systems and quota plans through language assuring that such plans are legal. The Michigan statute qualifies the use of such a plan by requiring that the state administrative agency concerned with equal employment opportunities be given an opportunity to disapprove the plan. ${ }^{38}$

In contrast to Michigan's and Oregon's encouragement of affirmative action plans, other states implicitly discourage the use of affirmative action plans. ${ }^{39}$ The statutes in these states note that they do not require an employer to grant preferen-

30. Id. §1-2524(b).

31. Id. $§ 1-2524(\mathrm{a})$.

32. IlL. ANN. STAT. ch. 68, § 2-105 (Smith-Hurd Supp. 1982-83).

33. Id. $\S 2-105(\mathrm{~B})(3)$.

34. Id.

35. Id. $\S 2-105(B)(4)$. Although not as detailed in its requirements as the Illinois statute, Indiana similarly requires all state agencies to formulate affirmative action plans to end the "underutilization" of handicapped persons. IND. CODE ANN. § 22-9-3-2 (Burns Supp. 1982). "Underutilization" is defined as "having fewer members of an affected class in a particular job category and classification than would be reasonably expected by their availability in the labor market for that job category and classification." Id. $\S 22-9-3-1(5)$. The term "handicapped persons" is defined for this section as "all persons who by reason of physical or mental defect are unable to achieve full vocational participation." Id. \$ 22-9-3-1(4). Minnesota requires that all contractors with state contracts valued at more than $\$ 50,000$, and who employ 20 or more individuals, have affirmative action plaris approved by the state commissioner of human rights. MINN. STAT. § 363.073(1) (Supp. 1981).

36. OR. REV. Stat. $\$ 659.100$ (1981).

37. Mich. Comp. Laws ANN. $\$ 37.1208$ (Supp. 1982-83).

38. Id.

39. Ga. Code Ann. § 66-504(a) (Supp. 1981); Md. Ann. Code art. 49B, § 16(h) (1979); MonT. Code ANN. $\$ 49-2-403$ (1981); NEB. Rev. Stat. $\$ 48-1113$ (1978); R.I. GeN. LAWS $\S 28-5-22$ (1979); UTAH CODE ANN. $\$ 34-35-6(2)$ (e) (Supp. 1981). 
tial treatment to a group or to an individual because of a mental handicap. ${ }^{40}$ Pennsylvania makes an exception from its general antidiscrimination statute allowing organizations dealing with the handicapped or disabled to give preferential treatment in employment to handicapped persons. ${ }^{41}$ Other employers, however, are discouraged from instituting preferential treatment programs since the act states: "Nothing in this act shall be construed to require any employer to hire any person with a job-related handicap or disability." 42

\section{III}

\section{DEFINITIONS}

The federal and state statutes are general antidiscrimination statutes, which are effectively limited by narrowly defined terms within the statutes.

\section{A. Statutory Definition of Mental Handicap}

1. Federal Definitions. The definition of handicapped for the purpose of sections 503 and 504 provides:

the term 'handicapped individual' means . . . any person who (i) has a physical or mental impairment which substantially limits one or more of such person's major life activities, (ii) has a record of such an impairment, or (iii) is regarded as having such an impairment. ${ }^{43}$

Under section 504, the term physical and mental impairment includes "any mental or psychological disorder, such as . . . emotional or mental illness . . . ."44 Major life activities for section 504 purposes are defined as "functions such as caring for one's self, performing manual tasks, walking, seeing, hearing, speaking, breathing, learning, and working." 45 Regulations under section 503 differ, giving primary attention to those life activities affecting employability. ${ }^{46}$

A person is not handicapped for purposes of either section unless the severity of the impairment is such that "it results in a substantial limitation of one or more major life activities." 47 While "substantially limits" has not been defined for purposes of section 504, it has been defined under section 503. That definition focuses on employability, stating that, "a handicapped individual is 'substantially limited' if he or she is likely to experience difficulty in securing, retaining or advancing in employment because of a handicap." 48 In E.E. Black, Ltd. v. Marshall, ${ }^{49}$ a district court adopted a case by case approach to deciding what is "substantially limiting"

40. Montana's language is slightly different: a handicap is not seen as a reason for "discrimination" "unless the nature of the service requires the discrimination for the legally demonstrable purpose of correcting a previous discriminatory practice." MONT. CODE ANN. § 49-2-403 (1981).

41. Pa. Stat. AnN. tit. 43, $\$ 955$ (b) (Purdon Supp. 1965-81).

42. Id. $\S 962(\mathrm{~d})$.

43. 29 U.S.C. $\$ 706(7)$ (B) (1976 \& Supp. IV 1980).

44. 45 C.F.R. $\$ 84.3($ j)(2)(i)(B) (1981); 34 C.F.R. $\$ 104.3(j)(2)(i)(B)$ (1981). Regulations under section 503 do not define impairment. However, in discussing the definition of "handicapped," they recognize that the "mentally restored" are included. 41 C.F.R. $\$ 60-741$ app. A (1981).

45. 45 C.F.R. $\$ 84.3(j)(2)(i i)(1981) ; 34$ C.F.R. $\S 104.3(j)(2)(i i)(1981)$.

46. 41 C.F.R. $\$ 60-741$ app. A (1981).

47. 45 C.F.R. $\S 84$ app. A (1981); 34 C.F.R. $§ 104$ app. A (1981) (emphasis added).

48. 41 C.F.R. $\$ 60-741.2$ (1981).

49. 497 F. Supp. 1088 (D. Hawaii 1980). 
under section 503. This approach includes the consideration of several factors: the number and types of jobs from which the impaired individual would be disqualified if the employer's criteria were used generally, ${ }^{50}$ the geographical area to which the individual has reasonable access, ${ }^{51}$ and the individual's own job expectations and training. ${ }^{52}$ "If an individual were disqualified from the same or similar jobs offered by employers throughout the area to which he had reasonable access, then his impairment or perceived impairment would have to be considered as resulting in a substantial handicap to employment."s3

The federal definition of handicapped persons includes those who have a record of an impairment as well as those who currently have a handicap. A person who "has a history of, or has been misclassified as having, a mental . . . impairment" 54 is, therefore, protected by the statute, as is one with a history of mental or emotional illness who no longer has the condition. These individuals are included in the definition because "the attitude of employers, supervisors, and coworkers toward that previous impairment may result in an individual experiencing difficulty in securing, retaining, or advancing in employment." 55

The definition of handicapped also includes those persons who are "regarded as having such an impairment." 56 This section has been defined as including a person:

(A) [having] a physical or mental impairment that does not substantially limit major life activities but . . . is treated by a recipient as constituting such a limitation; (B) [having] a physical or mental impairment that substantially limits major life activities only as a result of the attitudes of others toward such impairment; or (C) [having] none of the impairments defined [by this section] but is treated by a recipient as having such an impairment. ${ }^{57}$

This part of the definition might include those who never had a mental impairment but are nevertheless treated by an employer as having a handicap. ${ }^{58}$

2. State Definitions. Twenty-four states which prohibit employment discrimination against the mentally handicapped and the District of Columbia define, with varying degrees of specificity, what it means to be mentally handicapped. ${ }^{59}$ No

\footnotetext{
50. Id. at 1100 .

51. Id. at 1101 .

52. Id.

53. Id.

54. 45 C.F.R. $\S 84.3(j)$ (2)(iii) '(1981); 34 C.F.R. $\S 104.3(j)(2)$ (iii) (1981).

55. 41 C.F.R. $\$ 60-741$ app. A (1981).

56. 29 U.S.C. $\$ 706(7)$ (B)(iii) (1976 \& Supp. IV 1980).

57. 45 C.F.R. $\$ 84.3$ (j) (2)(iv) (1981); 34 C.F.R. $\$ 104.3(j)$ (2)(iv) (1981).

58. 45 C.F.R. $\$ 84$ app. A (1981); 34 C.F.R. \$ 104 app. A (1981). See 41 C.F.R. \$60-741 app. A

59. Conn. Gen. Stat. § 46a-51(13) (West Supp. 1982); D.C. Code AnN. § 1-2502(23) (1981); GA. CODE ANn. § 66-502(b), (c), (d)(1), (d)(2), (e), (f) (Supp. 1981); Ill. ANN. STat. ch. 68, § 1-103(I) (SmithHurd Supp. 1982-83); IND. CoDE ANN. § 22-9-1-3(q) (Burns Supp. 1982); IOWA CODE § 601A.2(11) (1975); Me. Rev. Stat. Ann. tit. 5, § 4553(7-A) (1979); Md. AnN. Code art. 49B, § 15(g) (1979); Мich. СoMP. Laws ANn. § 37.1103(d) (Supp. 1982-83); Minn. Stat. § 363.01(25) (Supp. 1981); Mont. Code ANN. § 49-2-101(13) (1981); NEB. REV. STAT. § 48-1102(8) (1978); N.H. REV. STAT. ANN. § 354-A:3(13) (Supp. 1981); N.J. Stat. ANn. § 10:5-5(q) (West Supp. 1982-83); N.M. Stat. ANN. § 28-1-3(K) (1978); N.Y. Exec. Law § 292(21) (McKinney 1982); Ohio Rev. Code Ann. § 4112.01(13) (Page 1980); Or. Rev. Stat. § 659.400(2), (3)(a), (3)(b), (3)(c)(A)-(C) (1981); Pa. Stat. Ann. tit. 43, §954(p) (Purdon Supp 1965-81); R.I. Gen. LaWs $\S 28-5-6(\mathrm{H})$ (i)-(iv) (Supp. 1981); TEX. HuM. Res. Code ANN. \$121.002(4) (Vernon 1980); Utah Code ANN. §34-35-2(14) (Supp. 1981); VT. STat. AnN. tit. 21, § 495(d)(5)(A)-(C),
} (1981) 
reported cases interpret state legislative attempts to devise a workable definition of mental handicap. Nevertheless, some basic generalizations are possible concerning the range of people the state statutes seek to cover, and the difficulties courts will eventually encounter in deciding whether a particular individual is protected from discrimination.

To create a manageable analytical framework, the various state definitions of mental handicap have been divided into three major categories. The categories are based on the specificity of the definitions, the first category being the least specific and the third category the most specific. There are some significant differences between definitions which are included in a particular category. The similarities between definitions in a given grouping outweigh the differences, however, providing useful comparisons between the three categories.

The first category of definitions, which includes thirteen states and the District of Columbia, ${ }^{60}$ is characterized by the use of vague, general words which do little to clarify the breadth of a given statute. For example, the Montana statute provides that "Mental handicap means any mental disability resulting in subaverage intellectual functioning or impaired social competence."61 It is difficult to determine how subaverage or how socially impaired one must be before the disability rises to the level of a "mental handicap." This problem is graphically illustrated by looking at the Montana statute in conjunction with the Connecticut statute. Connecticut's general antidiscrimination statute proscribes discrimination against anyone who is mentally handicapped, ${ }^{62}$ but the statute's section of definitions only discusses mental retardation. "Mental retardation means a significantly subaverage intellectual function existing with deficits in adaptive behavior and manifested during the development period."63 The similarity between the Connecticut definition of "mental retardation" and the Montana definition of mental handicap could lead to the conclusion that in Montana only drastically impaired persons, i.e., those who are mentally retarded, are afforded protection. This would be an anomalous result, since the majority of mentally retarded persons are incapable of performing most types of gainful employment, and the statute would leave unprotected those persons with lesser handicaps able to perform numerous types of jobs, but who may be denied employment on the basis of an irrational stigma associated with even minor mental handicaps. ${ }^{64}$

(6), (7)(A)-(C), (8), (9), (10), (11)(A)-(C) (Supp. 1982); W. VA. CODE § 5-11-3(t) (Supp. 1982); Wis. STAT. ANN. § 111.32(8)(a) (West Supp. 1982-83).

60. Conn. Gen. Stat. § 46a-51(13) (West Supp. 1982); D.C. Code AnN. § 1-2502 (23) (1981); Ill. ANN. STAT. ch. 68, § 1-103(I) (Smith-Hurd Supp. 1982-83); IND. CODE ANN. § 22-9-1-3(q) (Burns Supp. 1982); IOWA CoDE $\S 601 A .2(11)$ (1975); Мich. CoMp. LaWs ANN. §37.1103(d) (Supp. 1982-83); MinN. Stat. §363.01(25) (Supp. 1981); Mont. Code ANN. § 49-2-101(13) (1981); N.H. REV. STAT. ANN. § 354A:3(13) (Supp. 1981); N.M. Stat. AnN. § 28-1-3(K) (1978); PA. Stat. Ann. tit. 43, § 954(p) (Purdon Supp. 1965-81); Utah Code AnN. §34-35-2(14) (Supp. 1981); W. VA. Code § 5-11-3(t) (Supp. 1982); Wis.

STAT. ANN. \& 111.32(8)(a) (West Supp. 1982-83).

61. Mont. Code AnN. §49-2-101(13) (1981).

62. Conn. Gen. STAT. $§ 46 a-51(13)$ (West Supp. 1982).

63. Conn. Gen. Stat. § 46a-60(1), (2) (West Supp. 1982).

64. See Wald, The Legal Rights of People with Mental Disabilities in the Community: A Plea for Laissez Faire, in 2 Legal Rights of THE MeNTAlly HaNDicapPED 1033 (1973). 
The statutes of $\mathrm{Utah}^{65}$ and West Virginia ${ }^{66}$ define a handicap as any physical or mental impairment which substantially limits one or more "major life activities." Unfortunately, neither statute defines major life activity. The statutes contemplate that an individual may be unable to perform one or more major life activities, but may still be able to perform adequately as an employee. To clarify the problem that this type of definition presents, consider a hypothetical involving a job-seeker who has a history of mental illness: a schizophrenic whose disease is currently under control through the use of drugs. This schizophrenic would not be able to claim a current impairment of a major life activity because he would be presently functioning as a normal person. An employer may decide, however, that he does not want a schizophrenic, who could have a relapse at any time, potentially "polluting" the business environment. This type of situation, theoretically, would not be covered by either the Utah or West Virginia statutes.

Looking at these two statutes in a more practical light, a court in either state would be unlikely to allow employment discrimination against the above-mentioned schizophrenic. The court might cite the unlikelihood of such a legislative intent. Nevertheless, the above analysis suggests the need to word these statutes carefully to safeguard against uneven application and unnecessary litigation.

The Pennsylvania statute ${ }^{67}$ is typically ${ }^{68}$ general in its description of persons covered, but is unusual because it provides that the increased cost of insurance to an employer cannot be a basis for refusing employment to an otherwise qualified handicapped individual. ${ }^{69}$ Thus, the Pennsylvania legislature is mandating that employers make a specific accommodation. In contrast, the District of Columbia definition states that, " 'Physical handicap' means a bodily or mental disablement which may be the result of injury, illness or congenital condition for which reasonable accommodation can be made."70 A District of Columbia court could rule that increased cost of insurance is not a "reasonable accommodation" that an employer must make. Such a decision would remove protection for a large sector of the mentally handicapped population because the presence of a mentally handicapped individual in the workplace would probably raise the cost of insurance. ${ }^{71}$

A second category of definitions, which includes seven states, ${ }^{72}$ is characterized by a moderate amount of specificity and extensive lists of conditions which may

65. UTAH CODE ANN. $\$ 34-35-2(14)$ (Supp. 1981).

66. W. VA. CODE $§ 5-11-3(t)$ (Supp. 1982).

67. Pa. Stat. ANN. tit. $43 \S 954(p)$ (Purdon Supp. 1965-81).

68. See supra note 60 .

69. Pa. Stat. AnN. tit. $43 \S 954$ (p) (Purdon Supp. 1965-81).

70. D.C. CODE ANN. $§ 1-2502(23)$ (1981).

71. Not only may a company employing mentally handicapped individuals have to pay more for general liability insurance, but such a company may be placed in an "assigned risk pool" for purposes of setting its workmen's compensation premium. Generally, insurance companies underwriting the "assigned risk pool" charge an $8 \%$ premium to insure these high-risk companies. Interview with $\mathrm{H}$. Lynn Crayton, The Insurance Center of Durham (Nov. 1, 1982).

72. ME. Rev. Stat. ANN. tit. 5, § 4553(7-A) (1979); MD. ANN. Code art. 49B, § 15(g) (1979); NeB. Rev. STAT. § 48-1102(8) (1978); N.J. STAT. ANN. § 10:5-5(q) (West Supp. 1982-83); N.Y. Exec. LAW $\S$ 292(21) (McKinney 1982); Ohio Rev. Code ANn. \$ 4112.01 (13) (Page 1980); Tex. Hum. Res. Code ANN. § 121.002(4) (Vernon 1980). 
cause difficulties for a mentally handicapped individual in the employment market. The Nebraska statute is a typical example.

Disability shall mean any physical or mental condition, infirmity, malformation, or disfigurement which is caused by bodily injury, birth defect, or illness, including epilepsy or seizure disorders, and which shall include, but not be limited to, any degree of paralysis, amputation, lack of physical coordination, blindness or visual impediment, deafness or hearing impediment, muteness or speech impediment, or physical reliance on a dog guide, wheelchair, or other remedial appliance or device and shall also mean the physical or mental condition of a person which constitutes a substantial handicap, as determined by a physician, but is unrelated to such person's ability to engage in a particular occupation. ${ }^{73}$

Nebraska's statute takes great pains to protect specific groups of mentally and physically handicapped people. In addition, the statute closes what might have been a loophole for employers by saying that the definition of disability "shall include, but not be limited to . . ." the physical or mental conditions listed.

A notable omission from the Nebraska statute, one which finds expression only in the Maryland ${ }^{74}$ and Texas ${ }^{75}$ statutes, is the failure to mention the mentally retarded in the group of people who possess a physical or mental impairment. Perhaps the legislatures of Nebraska and the other four states in this category which do not mention the mentally retarded felt that this class of persons would not be able to function normally in a job. Nevertheless, the language "including but not limited to" indicates that a mentally retarded person would not be precluded from showing unlawful discrimination under such statutes. The statutes' failure to mention mental retardation, however would allow an employer to contend that the legislature felt that a person classified as mentally retarded could not have a handicap that is "unrelated to such person's ability to engage in a particular occupation . . . ."76

Ohio's statute is somewhat different from the other six statutes in the second category because it does not specifically mention mental handicap. It provides:

"Handicap" means a medically diagnosable, abnormal condition which is expected to continue for a considerable length of time, whether correctable or uncorrectable by good medical practice, which can reasonably be expected to limit the person's functional ability, including, but not limited to, seeing, hearing, thinking, ambulating, climbing, descending, lifting, grasping, sitting, rising, any related function, or any limitation due to weakness and significantly decreased endurance, so that he cannot perform his everyday routine living and working without significantly increased hardship and vulnerability to what are considered the everyday obstacles and hazards encountered by the nonhandicapped. ${ }^{77}$

The Ohio statute is comprehensive, and is unusual in its focus and care in delineating thę functions that a mentally handicapped person would have difficulty performing, but which might not bear on his ultimate ability to perform a particular task. The statute proscribes discrimination even if the handicap will result in "significantly, increased hardship" to the individual. In this situation an employer may want to argue that the contortions of the mentally handicapped

73. Neb. Rev. Stat. § 48-1102(8) (1978).

74. MD. ANN. CODE art. 49B, $\S 15(\mathrm{~g})(1979)$.

75. TEX. Hum. Res. CODE ANN. § 121.002(4) (Vernon 1980).

76. NEB. REV. STAT. § 48-1102(8) (1978).

77. Ohio Rev. Code ANN. § 4112.01 (13) (Page 1980). 
individual have an adverse psychological effect on the handicapped person's coworkers.

The Ohio statute also states that an employer cannot discriminate against a handicapped individual even though the handicap may result in "significantly increased . . . vulnerability to . . . everyday obstacles and hazards."78 This provision could have extraordinary ramifications because it suggests that even though a working environment may pose a substantial danger to a mentally handicapped individual, such an individual may voluntarily assume the risk despite an employer's objections. ${ }^{79}$

The final category of definitions includes only four states, ${ }^{80}$ and represents some of the more recent state attempts to grapple with the question of who is mentally handicapped. These last four states have been greatly influenced by the federal attempt to define mental illness.

The Rhode Island definition of mental handicap, although more detailed than the federal definition, has many provisions which are identical.

(H) The term "handicap" means any physical or mental impairment which substantially limits one or more major life activities, a record of such an impairment or is regarded as having such an impairment by any person, employer, labor organization or employment agency ... .

(i) "Physical or mental impairment" means any physiological disorder or condition, cosmetic disfigurement, or anatomical loss affecting one or more of the following bodily systems: neurological; musculoskeletal; special sense organs; respiratory, including speech organs; cardiovascular; reproductive, digestive; genito-urinary; hemo and lymphatic; skin; and endocrine; or any mental or psychological disorder, such as mental retardation, organic brain syndrome, emotional or mental illness, and specific learning disabilities.

(ii) "Major life activities" means functions such as caring for one's self, performing manual tasks, walking, seeing, hearing, speaking, breathing, learning, and working.

(iii) "Has a record of such impairment" means any history of, or has been misclassified as having, a mental or physical impairment that substantially limits one or more major life activities.

(iv) "Regarded as having an impairment" means has a physical or mental impairment that does not substantially limit major life activities but that is treated as constituting such a limitation; has a physical or mental impairment that substantially limits major life activities only as a result of attitudes of others toward such impairment; or has none of the impairments but is treated as having such an impairment. ${ }^{81}$

As the Rhode Island statute illustrates, this third category of definitions attempts to provide broad protection to mentally handicapped individuals who actually suffer from some sort of serious impairment, but who still can adequately perform a job. Perhaps more significantly, the definition provides protection for the individual who is perceived as having an impairment but who does not actually have

78. Id.

79. Rose v. Hanna Mining Co., 94 Wash. 2d 307, 616 P.2d 1229 (1980), reached a conclusion which also may be expected under the Ohio statute, supra note 77. In Hanna, an epileptic job applicant was not hired even though he could perform eleven of twelve jobs at a smelter which contained molten ore at thousands of degrees Fahrenheit. The Washington Supreme Court reversed the lower court's grant of summary judgment for the employer because there was a legitimate question whether a majority of people with the plaintiff's condition were incapable of performing the job.

80. GA. Code ANN. §66-502(b), (c), (d)(1), (d)(2), (e), (f) (Supp. 1981); OR. Rev. Stat. \$ 659.400(2), (3) (a), (3) (b), (3) (c) (A)-(C) (1981); R.I. GEN. LAWs $\$ 28-5-6($ H)(i)-(iv) (Supp. 1981); VT. STAT. ANN, tit. 21, $\S 495 \mathrm{~d}(5)(\mathrm{A})-(\mathrm{C}),(6),(7)(\mathrm{A})-(\mathrm{C}),(8),(9),(10),(11)(\mathrm{A})-(\mathrm{C})$ (Supp. 1982).

81. R.I. GEN. LAWS $\$ 28-5-6(\mathrm{H})$ (i)-(iv) (Supp. 1981). 
one. The Rhode Island statute avoids some of the problems present in the broad, sweeping language of the first category of definitions. ${ }^{82}$ The schizophrenic discussed in the hypothetical situation above would be protected in Rhode Island, because protection is specifically accorded not only to those with drastic impairments, but also to those in a middle range who have an impairment which does not rise to the level of limiting a major life activity, or individuals who have no impairment but are perceived as having one.

If Rhode Island limited its definition of mental handicap to the one sentence description in section $(\mathrm{H})$, the statute would be almost indistinguishable from definitions in the first category. It is the further qualification of the sweeping language of section (H) in subsections (i) - (iv) that breathes life into the statute, and demonstrates a deeper concern with the problems that face the mentally handicapped in the job market. In essence, subsections (i) - (iv) recognize that words like "impairment" or "major life activities" are not susceptible to easy definition, and that leaving the interpretation of these words to employers, and ultimately to the courts, results in a disservice to the people whom antidiscrimination statutes are designed to protect.

The definition of physical or mental impairment in the Rhode Island statute ${ }^{83}$ is broad enough so that an employer would find it difficult to think of a class of mentally handicapped persons not covered by the definition, yet at the same time specific enough to provide the courts with a meaningful standard to adjudicate a discrimination claim. Many of the statutes from all three categories define a mental handicap as impairing one or more "major life activities," 84 but only the third category carefully lists these major life activities to inform employers of what they may and may not do. Under the Rhode Island, ${ }^{85}$ Georgia, ${ }^{86}$ and federal ${ }^{87}$ statutes, a person may be limited in his ability to care for himself, perform manual tasks, see, hear, speak, breathe, learn, or even work, but if he can successfully perform the occupation, an employer may not refuse to hire the handicapped individual. The careful drafting of the statutes in the third category, although still in need of refinement, should eliminate much time-consuming litigation on the issue of who is protected from discrimination on the basis of a handicap. The words most likely to create serious problems are "substantially limits." When does the handicap substantially limit, and when does it completely limit, or preclude, effective functioning in the workplace? These are questions of statutory interpretation which will eventually be adjudicated on an ad hoc basis.

B. "Otherwise Qualified" and Bona Fide Occupational Qualification Exceptions

1. Federal Statutes. Section 504 prohibits discrimination against an "otherwise

82. See supra text accompanying notes 60-71.

83. R.I. GEN. LAWS $§ 28-5-6(H)$ (i) (Supp. 1981).

84. See, e.g., Utah Code ANN. § 34-35-2(14) (Supp. 1981); VT. Stat. AnN. tit. 21, § 495d(5)(A)-(C) (Supp. 1982).

85. R.I. GEN. LAWS $§ 28-5-6(\mathrm{H})$ (ii) (Supp. 1981).

86. GA. CODE ANN. § 66-502(f) (Supp. 1981).

87. 29 U.S.C. $706(7)$ (B) (1976 \& Supp. IV 1980). 
qualified handicapped individual."88 The term "otherwise qualified" was defined by the United States Supreme Court in Southeastern Community College v. Davis ${ }^{89}$ In Davis, an individual with a hearing problem wanted to attend nursing school at Southeastern Community College. The Court of Appeals for the Fourth Circuit defined "otherwise qualified" as one who could meet the qualifications in every respect except for his or her handicap. ${ }^{90}$ Under this definition, however, "a blind person possessing all of the qualifications for driving a bus except sight could be said to be 'otherwise' qualified for the job of driving."91 The Supreme Court rejected the Fourth Circuit's view, holding that "[a]n otherwise qualified person is one who is able to meet all of a program's requirements in spite of his handicap. ${ }^{92}$ The Court said that section 504 does not require a recipient of federal funds to "disregard the disabilities of handicapped individuals . . . [but says] only that mere possession of a handicap is not a permissible ground for assuming an inability to function in a particular context."93

The regulations promulgated pursuant to section 504 define an "otherwise qualified handicapped person" in less restrictive terms than did the Supreme Court. Such a person, with respect to employment, is one "who, with reasonable accommodation, can perform the essential functions of the job in question."94 Only the performance of essential functions rather than all functions is required because "handicapped persons should not be disqualified simply because they may have difficulty in performing tasks that bear only a marginal relationship to a particular job." 95 The definition of "otherwise qualified" under section 503 is similar to that under section 504.96

2. State Statutes. Every state statute allows an employer to discharge or to refuse to hire a mentally handicapped individual who is unable to perform a job adequately. ${ }^{97}$ The statutes do so either in their initial definition of mental handicap for the purposes of the employment discrimination statute or in their definition of

88. 29 U.S.C. $\$ 794$ (1976 \& Supp. IV 1980).

89. 442 U.S. 397 (1979).

90. Id. at 406 .

91. 45 C.F.R. $\$ 84$ app. A (1981); 34 C.F.R. $\$ 104$ app. A (1981).

92. 442 U.S. at 406.

93. Id. at 405 .

94. 45 C.F.R. $\$ 84.3(k)(1)(1981) ; 34$ C.F.R. $\$ 104.3(k)(1)(1981)$.

95. 45 C.F.R. $\$ 84$ app. A. (1981); 34 C.F.R. $\S 104$ app. A (1981).

96. 41 C.F.R. $\$ 60-741.2$ (1981).

97. Conn. Gen. Stat. $\S 46 a-60(a)(1)$, (2) (West Supp. 1982); D.C. Code AnN. $\$ 1-2502(23)$ (1981); Fla. Stat. ANN. $\S 23.167$ (8)(a) West Supp. 1982); Ga. Code ANN. § 66-504(a) (Supp. 1981); Ill. ANN. STAT. ch. 68, § 1-103(I)(1) (Smith-Hurd Supp. 1982-83); Ind. CODE ANN. \$ 22-9-1-3(q) (Burns Supp. 1982); Iowa Code $\S 601$ A.2(11) (1975); ME. Rev. STat. ANN. tit. 5, § 4572, 4573(4) (1979); MD. ANN. Code art. 49B, $\$ 16(\mathrm{a})(1)$, (g) (1979); Mass. ANN. LAws ch. 149, $\$ 24 \mathrm{~K}$ (Michie/Law. Co-op. 1976); Mich. Comp. Laws AnN. \$ 37.1202(1) (Supp. 1982-83); Minn. Stat. § 363.02(5) (Supp. 1981); MonT. Code ANN. § 49-2-303(1)(a) (1981); Neb. Rev. STAT. § 48-1102(8), 1108(1) (1978); N.H. ReV. STAT. ANN. § 354A:3(13), 8(I) (Supp. 1981); N.J. STaT. ANN. \& 10:5-4.1 (West Supp. 1982-83); N.M. STAT. ANN. § 28-1-7(D) (1978); N.Y. ExeC. LAW § 292(21) (McKinney 1982); N.C. GEN. STAT. § 128-15.3 (1981); OHIO REV. Code Ann. § 4112.02 (L) (Page Supp. 1982); OR. Rev. Stat. § 659.425 (1)(a) (1981); Pa. Stat. AnN. tit. $43 \S 955$ (Purdon Supp. 1965-81); R.I. GeN. Laws § 28-5-7(D) (1979); TENN. CodE ANN. § 8-50-103(a) (1980); TeX. HuM. Res. Code ANN. \$ 121.003(f) (Vernon 1980); UTAh Code ANN. § 34-35-6(2)(a) (Supp. 1981); Vt. Stat. ANn. tit. 21, § 495(a)(1) (Supp. 1982); Wash. Rev. Code ANN. $\$ 49.60 .180(1)$ (Supp. 1982); W.VA. Code $\S$ 5-11-9(a) (Supp. 1982); WiS. STAT. ANN. §111.34(2)(a) (West Supp. 1982-83). 
unfair employment practice. Generally, one of three types of wording is used. ${ }^{98}$ First, some statutes state that the particular mental handicap must have no relevance to the specific job in question. ${ }^{99}$ Second, some statutes provide that the mental handicap cannot impede performance of the job. ${ }^{100}$ Finally, some statutes allow an exemption when a specific mental ability is a bona fide occupational qualification for the job. ${ }^{101}$

Only four states and the District of Columbia have progressed beyond these general definitions of job relatedness to provide additional statutory guidance as to the respective rights and obligations of the mentally ill individual and his employer. ${ }^{102}$ The District of Columbia ${ }^{103}$ and Oregon ${ }^{104}$ favor the employee by requiring that the employer make reasonable accommodation for the mentally handicapped employee. Rhode Island ${ }^{105}$ and Ohio ${ }^{106}$ provide some protection for the mentally handicapped individual by requiring that an employer who inquires about a mental handicap during the hiring process do so only if the appropriate state commission on human rights has certified the absence of such handicap as a bona fide occupational qualification. Thus, an independent third party makes the initial determination as to job relatedness. In contrast, Indiana ${ }^{107}$ gives the employer control over the definition of reasonable job performance by specifying not only that the individual must be able to perform the job safely and efficiently, but that the performance must be according to "the standards set by the employer."108

98. Maine, Maryland, and Nebraska each combine two of these types of wording in their statutory provisions. ME. REV. STAT. ANN. tit. 5, $\$ \S 4572,4573(4)$ (1979) (bona fide occupational qualification and impairment of performance); MD. ANN. CODE art. 49B, $\S 16(\mathrm{a})(1)$, (g) (1979) (impairment of performance and bona fide occupational qualification); NEB. REV. STAT. $\$ \S 48-1102(8), 1108(1)$ (1978) (relevance to job and bona fide occupational qualification).

99. Ill. ANN. STAT. ch. 68, § 1-103(I)(1) (Smith-Hurd Supp. 1982-83); IND. CodE ANN. § 22-9-1-3(q) (Burns Supp. 1982); IOWA Code $\S 601$ A.2(11) (1975); Mich. CoMP. LaWs ANN. § 37.1202(1) (Supp. $1982-$ 83); Neb. Rev. Stat. § 48-1102(8) (1978); N.H. Rev. STat. ANN. § 354-A:3(13) (Supp. 1981); N.M. STAT. ANN. § 28-1-7(D) (1978).

100. D.C. Code Ann. § 1-2502(23) (1981); GA. Code AnN. § 66-503(b)(1), 504(a) (Supp. 1981); ME. Rev. Stat. ANN. tit. 5, § 4573(4) (1979); MD. ANN. Code art. 49B, § 16(a)(1) (1979); Mass. AnN. LaWS ch. 149, § 24K (Michie/Law. Co-op. 1976); MinN. STAT. \$ 363.02(5) (Supp. 1981); Mont. Code AnN. $\S$ 49-2-303(1)(a) (1981); N.J. STAT. ANN. § 10:5-4.1 (West Supp. 1982-83); N.Y. EXEC. LAW § 292(21) (McKinney 1982); N.C. Gen. Stat. § 128-15.3 (1981); Oho Rev. Code AnN. \$ 4112.02(L) (Page Supp. 1982); Or. Rev. Stat. § 659.425(1)(a) (1981); Tenn. Code AnN. § 8-50-103(a) (1980); TeX. Hum. Res. CODE ANN. § 121.003(f) (Vernon 1980); Wash. Rev. Code ANn. § 49.60.180(1) (Supp. 1982); W.VA. CODE § 5-11-9(a) (Supp. 1982); WIS. STAT. ANN. § 111.34(2)(a) (West Supp. 1982-83).

101. Conn. Gen. Stat. \$ 46a-60(a)(1), (2) (West Supp. 1982); Fla. Stat. AnN. § 23.167(8)(a) (West Supp. 1982); Me. Rev. Stat. AnN. tit. 5, § 4572 (1979); MD. AnN. Code art. 49B, § 16(g) (1979); NeB. Rev. Stat. \$ 48-1 108(1) (1978); N.H. Rev. Stat. AnN. \$ 354-A:8(I) (Supp. 1981); PA. Stat. AnN. tit. 43, $\S 955$ (Purdon Supp. 1965-81); R.I. GeN. Laws § 28-5-7(D) (1979); UTAH Code ANN. § 34-35-6(2)(a) (Supp. 1981); VT. Stat. ANN. tit. 21, § 495(a)(1) (Supp. 1982).

102. D.C. CODE ANN. § 1-2502(23) (1981); IND. CODE ANN. § 22-9-1-13(a) (Burns Supp. 1982); ОhiO Rev. Code Ann. \$ 4112.02 (E) (Page Supp. 1982); OR. Rev. Stat. 659.425(1)(a) (1981); R.I. Gen. Laws $\S 28-5-7$ (D) (1979).

103. D.C. Code ANN. § 1-2502(23) (1981).

104. OR. REV. STAT. $\$ 659.425(1)$ (a) (1981).

105. R.I. GEN. LAWS $§$ 28-5-7(D) (1979).

106. Ohio Rev. Code ANn. \$ 4112.02(E) (Page Supp. 1981).

107. IND. CODE ANN. § 22-9-1-13(a) (Burns Supp. 1982),

108. Id. 


\section{Coverage of Employers and Employees}

1. Federal Statutes. Section 504 prohibits discrimination against handicapped persons "under any program or activity receiving federal financial assistance."109 This phrase, however, has not been interpreted to mean any federal assistance but rather only those programs whose purpose is to provide employment. ${ }^{10}$ In United States v. Cabrini Medical Center, ${ }^{11}$ an employee who took Valium to quiet his nerves lost his temper at work and beat a faucet with a cane until the faucet broke. The employee was discharged and filed a complaint with the Department of Health and Human Services' Office for Civil Rights claiming he was discharged because of his mental disability. The hospital refused to allow the department to investigate and the government brought an action to force compliance. The district court concluded that "section 504 was designed to eliminate discrimination under any program or activity receiving federal assistance 'without regard to the purpose for which the funds were received." "112 The hospital received federal assistance in the form of Medicare and Medicaid. The court of appeals, however, held that Medicare and Medicaid were not sufficient to bring the hospital within section 504 because the objective of those payments was not to provide employment. ${ }^{113}$ The court based its decision on section 505(a)(2) which provides that the remedies for section 504 are the same as those under Title VI of the Civil Rights Act of 1964. ${ }^{114}$ Title VI is limited to aid having a "primary objective" of providing employment. ${ }^{115}$ Therefore, there is no judicial remedy unless providing employment is a primary objective of the aid.

The phrase "any federal financial assistance" has been further qualified to mean that even if the purpose of the aid is to provide employment, the individual must be an intended beneficiary of the assistance. In Simpson v. Reynolds Metals Co. ${ }^{116}$ Reynolds received federal assistance in the form of on-the-job training which allows veterans to receive money from the government while they participate. Simpson, who was not part of this program, claimed he had been dismissed because of his alcoholism. The court decided " $t]$ he statute does not . . . generally forbid discrimination against the handicapped by recipients of federal assistance. . . . To be actionable, the discrimination must come in the operation of the program or manifest itself in a handicapped individual's exclusion from the program or a diminution of the benefits he would otherwise receive from the program."117 Considering the same question in Simon v. St. Louis City Police

109. 29 U.S.C. $\$ 794$ (1976 \& Supp. IV 1980). For a definition of federal financial assistance, see 45 C.F.R. $\$ 84.3(\mathrm{~h})(1981)$.

110. See Carmi v. Metropolitan St. Louis Sewer Dist., 620 F.2d 672 (8th Cir. 1980), cert. denied, 449 U.S. 892 (1980); Trageser v. Libbie Rehabilitation Center, Inc., 590 F.2d 87 (4th Cir. 1978), cert. denied, 442 U.S. 947 (1978).

111. 639 F.2d 908 (2d Cir. 1981).

112. Id. at 910 .

113. Id. at 909.

114. 29 U.S.C. $\$ 794 a$ (1976 \& Supp. IV 1980).

115. 42 U.S.C. $\$ 2000$ d-3 (1976).

116. 629 F.2d 1226 (7th Cir. 1980).

117. Id. at 1232 . 
Department, ${ }^{118}$ a district court in Missouri stated that the "plaintiff must allege that the particular job category in which he was allegedly discriminated was a program or activity receiving federal financial assistance."119 In Simon, the plaintiff was denied employment as a commissioned police officer. He did not, however, allege that he was denied all employment by the department or that the particular job which he was denied received federal assistance. ${ }^{120}$

The term "federal financial assistance" has also been held not to include government agencies. ${ }^{121}$ Discrimination in employment by the Federal Government is actionable under section 501 rather than section 504. ${ }^{122}$ Because of these restrictions, the courts have protected fewer mentally ill employees than the statute appears to reach. Only non-Federal government employees, participating in a program funded by the Federal Government for the purpose of providing employment, are protected under section 504.

Section 503 requires federal contractors with contracts in excess of $\$ 2,500$ to take affirmative action to employ qualified handicapped individuals. ${ }^{123}$ Whether this section protects employees working for a contractor on a job other than the federally contracted job is unclear.

2. State Statutes. Definitions of the types of employers and employees covered by mental handicap employment discrimination statutes vary from state to state. ${ }^{124}$ Some statutes provide an extremely broad definition, extending coverage to any employer conducting business in the state, ${ }^{125}$ or to all public and private employers. ${ }^{126}$ Other statutes specify that they apply to all state agencies, ${ }^{127}$ or limit the extent of coverage of private employers to those employing a certain

118. 14 Fair Empl. Prac. Cases (BNA) 1363 (E.D. Mo. 1977).

119. Id. at 1364 .

120. Id.

121. Coleman v. Darden, 595 F.2d 533 (10th Cir. 1979), cert. denied, 444 U.S. 927 (1979).

122. Id. at 538. See also 29 U.S.C. § 791 (1976 \& Supp. IV 1980).

123. See supra note 16.

124. Conn. Gen. Stat. §46a-60 (West Supp. 1982); D.C. Code AnN. § 1-2502(10) (1981); Fla. Stat. ANN. § 23.167(1) (West Supp. 1982); Ga. Code ANN. § 66-502(g) (Supp. 1981); Ill. ANn. STAT. ch. 68, § 2-101(B)(b), (c), (d) (Smith-Hurd Supp. 1982-83); IND. CODE ANN. § 22-9-1-3(h) (Burns Supp. 1982); Iowa CODE § 601A.2(5) (1975); ME. Rev. Stat. ANN. tit. 5, § 4553(4) (1979); MD. ANN. Code art. 49B, $\S 15$ (b) (1979); Mass. ANN. Laws ch. 149, § 24K (Michie/Law. Co-op. 1976); Mich. Comp. Laws ANN. § 37.1201 (b) (Supp. 1982-83); MinN. STat. § 363.01(15) (Supp. 1981); MONT. Code ANN. § 49-2-101(7), (8) (1981); NEB. Rev. STAT. § 48-1102(2) (1978); N.H. Rev. STAT. ANN. § 354-A:4(5) (1966); N.J. STAT. ANN. § 10:5-5(e), (f) (West Supp. 1982-83); N.M. STAT. ANN. § 28-1-2(B) (1978); N.Y. EXEC. LAW § 292(5), (6) (McKinney 1982); N.C. Gen. STAT. § 128-15.3 (1981); OhIO Rev. Code ANN. § 4112.01 (2), (3) (Page 1980); Or. Rev. Stat. § 659.400(1) (1981); PA. Stat. ANN. tit. 43, § 954(b) (Purdon Supp. 1965-81); R.I. Gen. Laws 28-5-6(B) (Supp. 1981); Tenn. Code AnN. \& 8-50-103(a) (1980); TeX. Hum. Res. Code ANn. $\S 121.003(f)$ (Vernon 1980); UTAH CODE ANN. \$ 34-35-2(5) (Supp. 1981); VT. STAT. ANN. tit. 21, $\S 495 d$ (1) (Supp. 1982); WASh. Rev. Code ANN. $\$ 49.60 .180$ (Supp. 1982); W.VA. Code § 5-11-3(d) (Supp. 1982); Wis. STAT. ANN. §111.32(5), (6) (West Supp. 1982-83).

125. Conn. Gen. Stat. 46a-60(a)(1) (West Supp. 1982); Fla. Stat. Ann. § 23.167(1) (West Supp. 1982); Mass. Ann. Laws ch. 149, $\$ 24 \mathrm{~K}$ (Michie/Law. Co-op. 1976); TeX. Hum. Res. Code AnN. $\S 121.003(f)$ (Vernon 1980); Vt. Stat. ANN. tit. 21, § 495d(1) (1978); WASh. Rev. Code ANN. $§ 49.60 .180$ (Supp. 1982).

126. N.J. Stat. ANN. § 10:5-5(e) (West Supp. 1982-83); Tenn. Code ANn. § 8-50-103(a) (1980).

127. Conn. Gen. Stat. §46a-70 (West Supp. 1982); N.C. Gen. Stat. § 128-15.3 (1981); Tenn. CODE ANN. § 8-50-103(a) (1980); Wis. STAT. § 111.32(3) (Supp. 1982-83). 
number of people. ${ }^{128}$ Charitable, religious, and fraternal nonprofit organizations are frequently excluded from coverage. ${ }^{129}$

Coverage of employees is more consistently defined from state to state than is coverage of employers. As opposed to an employer, an employee is defined by specifying which employees are excluded from coverage rather than which employees are covered by the statute. ${ }^{130}$. The exemptions usually include two categories: those employed by a close relative, such as a parent or a child, ${ }^{131}$ and any person employed in domestic service. ${ }^{132}$

\section{ENFORCEMENT PROCEDURES}

Statutes provide two procedural routes through which a mentally handicapped

128. Fla. STAT. ANN. \$ 23.162(6) (West Supp. 1982) (15 or more employees for each working day in each of 20 or more calendar weeks in the current or preceding calendar year); GA. CODE ANN. $\$ 66-502(\mathrm{~g})$ (Supp. 1981) (15 or more employees); IND. CODE ANN. \$ 22-9-3(h) (Burns Supp. 1982) (six or more employees); IOWA CODE § 601A.6(5)(a) (Supp. 1982-83) (four or more employees); MD. ANN. CoDE art. 49B, § 15(b) (1979) (15 or more employees); Mich. CoMP. LAWS ANN. § 37.1201(b) (Supp. 1982-83) (four or more employees); N.H. REV. STAT. ANN. \$ 354-A:4(5) (1966) (six or more employees); N.M. STAT. ANN. $\S 28-1-2$ (B) (1978) (four or more employees); N.Y. ExEC. LAW § 292(5) (1982) (four or more employees); Ohio Rev. Code AnN. \$ 4112.01 (2) (Page 1980) (four or more employees); Or. Rev. STAT. § 659.400(1) (1981) (six or more employees); PA. STAT. ANN. tit. 43, \$ 954(b) (Purdon Supp. 1965-81) (four or more employees); R.I. GEN. Laws \$ 28-5-6(B) (Supp. 1981) (four or more employees); UTAH CODE ANN. \$ 3435-2(5) (Supp. 1981) (25 or more employees); WASH. REv. CODE ANN. $\$ 49.60 .040$ (Supp. 1982) (eight or more employees); W.VA. CoDE $§ 5-11-3$ (d) (Supp. 1982) (12 or more employees).

129. IND. Code ANN. § 22-9-1-3(h) (Burns Supp. 1982); Me. Rev. STAT. ANN. tit. 5, § 4553(4) (1979); MD. Ann. Code art. 49B, § 15(b) (1979); Mont. Code AnN. § 49-2-101(8) (1981); Neb. Rev. STAt. § 481102(2) (1978); N.H. REV. STAT. ANN. § 354-A:4(5) (1966); UTAH CodE ANN. § 34-35-2(5) (Supp. 1981); Wash. Rev. Code AnN. § 49.60 .040 (Supp. 1982); W. VA. Code $§ 5-11-3$ (d) (Supp. 1982); WiS. STAT. ANN. $\S 111.32(6)$ (b) (Supp. 1982-83).

130. Ill. Ann. Stat. ch. 68, § 2-101(A) (Smith-Hurd Supp. 1982-83); Ind. Code AnN. § 22-9-1-3(i) (Burns Supp. 1982); IOWa CODE $\S 601$ A.2(6), .6 (1975); ME. Rev. STAT. ANN. tit. 5, $\S 4553(3)$ (1979); MD. AnN. Code art. 49B, § 15(e) (1979); Mich. Comp. Laws AnN. § 37.1201 (a) (Supp. 1982-83); Minn. STAT. $\S 363.02(1)$ (Supp. 1981); Neb. Rev. Stat. \$§ 48-1102(6), 1103 (1978); N.H. Rev. Stat. AnN. § 354A:4(6) (1966); N.J. STAT. ANN. § 10:5-5(e) West Supp. 1982-83); N.Y. ExeC. LaW § 292(6) (McKinney 1982); Ohio Rev. Code Ann. §4112.01(3) (Page 1980); Pa. Stat. AnN. tit. 43, § 954(c) (Purdon Supp. 1965-81); R.I. Gen. LaWs § 28-5-6(C) (Supp. 1981); Utah Code AnN. § 34-35-2(6) (Supp. 1981); W. VA. Code §5-11-3(3) (Supp. 1982); WIS. StaT. ANN. § 111.32(5) (Supp. 1982-83).

131. D.C. CODE ANN. § 1-2502(10) (1981); IND. CODE ANN. § 22-9-1-3(i) (Burns Supp. 1982); IOWA Code $\S 601$ A.6(5)(a) (Supp. 1982-83); ME. Rev. Stat. AnN. tit. 5, § 4553(3) (1979); Mich. Comp. LaWs ANN. \$ 37.1202(2) (Supp. 1982-83); MINN. STAT. \$ 363.02 (Supp. 1981); Neb. REV. STAT. § 48-1103 (1978); N.H. Rev. Stat. ANN. § 354-A:4(6) (1966); N.J. STAT. ANN. § 10:5-5(f) (West Supp. 1982-83); N.Y. Exec. LAW $\S 292(6)$ (McKinney 1982); PA. STAT. ANN. tit. 43, § 954(c) (Purdon Supp. 1965-81); R.I. Gen. Laws § 28-5-6(C) (Supp. 1981); Wash. Rev. Code AnN. § 49.60.040 (Supp. 1982); W. VA. Code § 5-11-3(e) (Supp. 1982); Wis. STAT. ANN. § 111.32(5) (Supp. 1982-83).

132. D.C. Code ANN. § 1-2502(10) (1981); Ill. ANN. STAT. ch. 68, § 2-101(A)(2) (Smith-Hurd Supp 1982-83); IND. CODE ANN. § 22-9-1-3(i) (Burns Supp. 1982); IOWA CodE § 601 A.6(b), (c) (Supp. 1982-83); Mich. Comp. Laws ANN. § 37.1201 (a) (Supp. 1982-83); MinN. STAT. § 363.02(1) (Supp. 1981); NeB. REV. STAT. § 48-1103 (1978); N.H. REV. STAT. ANN. § 354-A:4(6) (1966); N.J. STAT. ANN. § 10:5-5(f) (West Supp. 1982-83); N.Y. EXEC. LAW § 292(6) (McKinney 1982); OHIO REV. Code ANN. § $4112.01(3)$ (Page 1980); PA. Stat. ANN. tit. 43, § 954(b) (Purdon Supp. 1965-81); R.I. Gen. Laws $\$ 28-5-6(C)$ (Supp. 1981); Utah Code ANN. § 34-35-2(6) (Supp. 1981); Wash. Rev. Code ANN. $\$ 49.60 .040$ (Supp. 1982); W. VA. CODE \$ 5-11-3(d) (Supp. 1982). Exemptions are not necessarily limited to these two categories. Illinois, for example, also excludes individuals employed in agricultural labor, elected public officials, certain staff members of elected public officials, and the chief administrators of state agencies. ILL. ANN. STAT. ch. 68, $\S 2 \cdot 101(A)$ (2) (Smith-Hurd Supp. 1982-83). 
individual who has experienced employment discrimination may obtain relief. The first route is by application to an administrative agency statutorily empowered to handle such complaints; the second is by resort to the judicial system.

\section{A. Administrative Remedies}

1. Section 503. An administrative remedy is expressly provided in section 503 of the Federal Rehabilitation Act. ${ }^{133}$ A mentally ill person who believes he has been discriminated against may file a complaint with the OFCCP of the Department of Labor. ${ }^{134}$ Under OFCCP procedures, a complaint must be filed within 180 days of the date of the alleged violation. ${ }^{135}$ The Department of Labor then investigates the complaint. ${ }^{136}$ When a violation is found, the Department tries to settle it informally and if that is not possible, a formal hearing is held to determine if there has been a violation of the Act. ${ }^{137}$ To gain compliance, the OFCCP may seek appropriate judicial action to enforce the contractual provision included in federal contracts requiring affirmative action. ${ }^{138}$ The OFCCP may also withhold any payments due on the contract ${ }^{139}$ or terminate it. ${ }^{140}$

2. Section 504. The text of section 504 does not provide an administrative remedy. Section 505, however, provides that the remedies and procedures for section 504 are those of Title VI of the Civil Rights Act of 1964. ${ }^{141}$ The regulations promulgated under section 504 provide the same. ${ }^{142}$

Recipients of federal financial assistance from the Department of Health and Human services are required to submit periodic compliance reports. ${ }^{143}$ In addition, a person who believes he has been discriminated against can file a complaint with the Department of Health and Human Services Office for Civil Rights (OCR) within 180 days of the date of the alleged discrimination. ${ }^{144}$ When the report, a complaint, or other information indicates a failure to comply with the regulations, the Department investigates. ${ }^{145}$ If violations are found, OCR tries to settle the matter informally. ${ }^{146}$ If that is not successful, OCR may suspend or terminate the benefits after a hearing to determine the existence of a violation ${ }^{147}$ or refer the matter to the Justice Department with a recommendation that appropriate proceedings be brought. ${ }^{148}$

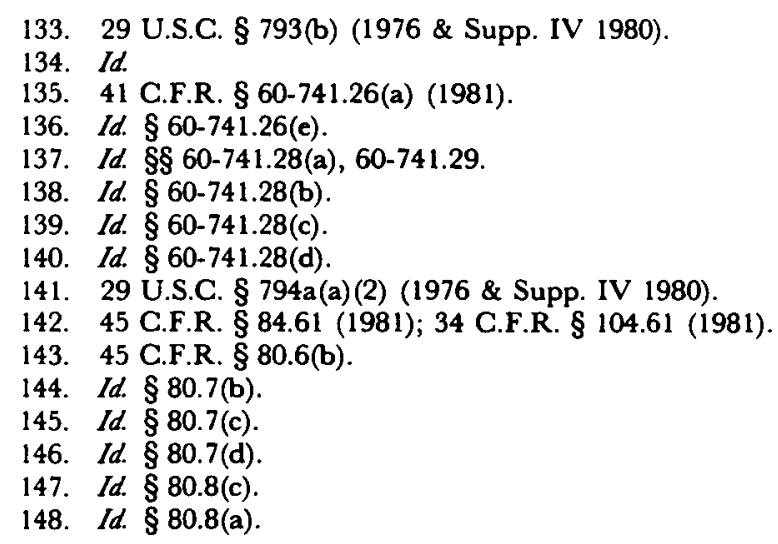


3. States. Administrative remedies are the most common route for relief under the state statutes. ${ }^{149}$ Administrative agencies, usually having a name such as the human rights commission or the equal employment opportunity commission, are generally composed of fewer than ten individuals appointed by the governor, although they may at times delegate their duties. ${ }^{150}$ The procedure for alleging an employment discrimination violation is similar to the federal procedure in all of the states which have such a commission. The following description generalizes the basic elements of state procedure; however, the details vary in different jurisdictions.

To gain protection against discrimination an aggrieved individual must file a sworn written complaint against a specified employer within a certain period of time after the alleged violation has occurred. After allowing the employer to respond to the allegations, the commission determines if probable cause of a violation exists. If the commission finds cause to believe that there has been a violation, a period of arbitration and conciliation ensues, during which the commission attempts to negotiate an agreement between employer and employee. If such an agreement is reached, it is enforceable by court decree in the event of a violation. If this informal process fails, the commission may order a hearing, at which both sides have an opportunity to present evidence, cross-examine witnesses and be represented by counsel. At this stage, the commission staff will often represent the complainant. Based on this hearing, the commission makes findings of fact and conclusions of law, and issues a decree either dismissing the complaint or finding a violation and providing for statutory remedies. Should either party wish to appeal such a decree he may do so in the lower courts of the state, subject to appellate judicial review. If not appealed, such an order is subject to enforcement by the state courts.

\section{B. Judicial Action}

The second enforcement route is a civil court action.

149. Conn. Gen. Stat. $§ 46 a-82$ (West Supp. 1982); D.C. Code Ann. § 1-2544 to 2555 (1981); Fla. Stat. Ann. § 23.167(10) (West Supp. 1982); IlL. ANN. STAT. ch. 68, § 7-102 to 104, 8-103 to 111 (SmithHurd Supp. 1982-83); Ind. Code ANn. § 22-9-1-6 (Burns Supp. 1982); IOWA Code § 601A.15, .17 (Supp. 1982-83); ME. Rev. Stat. AnN. tit. 5, § $4611-4612$ (1979 \& Supp. 1981-82); MD. Ann. Code art. 49B, $\S \S 4$, 9-13 (1979); Mass. Ann. Laws ch. 149, § 24C (Michie/Law. Co-op. 1976); Mich. Comp. Laws AnN. $\S 37.1605$ (Supp. 1982-83); MinN. STAT. § 363.06, .071, 072 (Supp. 1981); MoNT. Code ANN. § 49-2-501 to -508 (1981); Neb. Rev. STAT. $\$ 48-1118$ to -1120 (1978); N.H. REV. STAT. ANN. $\$ 354-A: 9,: 10$ (1966 \& Supp. 1981); N.J. Stat. ANN. § 10:5-13 to -24 (West Supp. 1982-83); N.M. STAT. ANN. § 18-1-10 to -13 (1978); N.Y. EXEC. LAw § 297-298 (McKinney 1982 \& Supp. 1982-83); Ohio ReV. Code AnN. \$ 4112.05 to 06 (Page 1980); OR. Rev. Stat. §659.435 (1981); PA. Stat. AnN, tit. 43, § 959-960 (Purdon Supp. 1965-81); R.I. GeN. LAws § 28-5-17 to 28-5-28 (1979 \& Supp. 1981); TENN. COde ANN. § 8-50-103(B) (1980); UtAH CODE ANN. § 34-35-7 to 34-35-8 (Supp. 1981); W. VA. Code § 5-11-10 to 5-11-11 (1979); Wis. STAT. ANN. § 111.39 (West Supp. 1982-83).

150. Conn. Gen. Stat. § 46a-52 (West Supp. 1982); Fla. Stat. AnN. $§ 23.163$ (West Supp. 1982); Ill. ANN. STAT. ch. 68, § 8-101 (Smith-Hurd Supp. 1982-83); IND. CODE ANN. § 22-9-1-4 (1976); IOWA Code $\S 601$ A.3 (Supp. 1982-83); ME. Rev. Stat. AnN. tit. 5, § 4561 (1979); MD. ANN. Code art. 49B, 11 (1979); Mont. Code ANN. § 2-15-1706 (1981); Neb. Rev. Stat. § 48-1116 (1978); N.H. Rev. STAT. ANN. § 354-A:4 (1966); N.J. STAT. ANN. § 10:5-7 (West 1976); N.M. STAT. ANN. § 28-1-3(A) (1978); OHIO REv. Code AnN. \$4112.03 (Page 1980); PA. Stat. ANN. tit. 43, § 956 (Purdon 1964 \& Supp. 1965-81); R.I. Gen. Laws § 28-5-8 (1979); TenN. Code ANN. § 4-21-103 (1980); W. VA. Code $§ 5-11-5$ (Supp. 1982). 
1. Federal System. In the federal system, a plaintiff alleging discrimination on the basis of a mental handicap must first come within the narrow definitions discussed above. He must next convince the court that there is a private right of action under sections 503 and 504. A plaintiff may allege violations of both sections if he satisfies each section's jurisdictional requirements. ${ }^{151}$

Most courts considering the question have found a private right of action under section 504. ${ }^{152}$ The courts are split, however, over the question of the existence of a private right of action under section 503.153 The factors set out in Cort $v$. $A s h^{154}$ are used to determine when a private right of action is implied by a statute. These factors are:

a. Is the plaintiff one of the class for whose especial benefit the statute was enacted?

b. Is there any indication of legislative intent, explicit or implicit, either to create such a remedy or to deny one?

c. Is it consistent with the underlying purposes of the legislative scheme to imply such a remedy for the plaintiff?

d. Is the cause of action one traditionally relegated to state law, in an area basically the concern of the states, so that it would be inappropriate to infer a cause of action based solely on federal law? ${ }^{155}$

a. Is Plaintiff One of the Class for Whose Especial Benefit the Statute Was Enacted? The court in Hart $v$. County of Alameda ${ }^{156}$ unequivocally decided that the handicapped were the class for whose benefit sections 503 and 504 were enacted. ${ }^{157}$ The Fifth Circuit, however, in Rogers v. Frito-Lay, Inc. ${ }^{158}$ considering an action under section 503, took the position that it was not clear that the handicapped were the class for whom the statute was enacted. The court noted that the language of section 503 is different from that in sections 504, 601, and 901. Section 503 puts the duty on the government, not on the general public, to prevent discrimination by requiring "contractors to take affirmative steps to employ . . . handicapped persons." 159

b. Legislative Intent. In considering legislative intent, the Hart court noted that the legislative history of the 1974 amendments which added the definition of

151. See Simpson v. Reynolds Metals Co., 629 F.2d 1226 (7th Cir. 1980); Hart v. County of Alameda, 485 F. Supp. 66 (N.D. Cal. 1979).

152. Doe v. New York Univ., 666 F.2d 761 (2d Cir. 1981); Doe v. Syracuse School Dist., 508 F. Supp. 333 (N.D.N.Y. 1981); Drennon v. Philadelphia Gen. Hosp., 428 F. Supp. 809 (E.D. Pa. 1977); Halderman v. Pennhurst State School \& Hosp., 446 F. Supp. 1295 (E.D. Pa. 1977), modified, 612 F.2d 84 (3d Cir. 1979 ). Lloyd v. Regional Trans. Auth., 548 F.2d 1277 (7th Cir. 1977), found a private right of action since at that time there were no administrative procedures. It expressly left open the question of what it would decide once the administrative procedures were in place. Id. at $1286 \mathrm{n} .29$.

153. See, e.g., Simpson v. Reynolds Metals Co., 629 F.2d 1226 (7th Cir. 1980) (no private right of action); Rogers v. Frito-Lay, Inc., 611 F.2d 1074 (5th Cir. 1980) (no private right of action); Clark v. FELEC Serv., 489 F. Supp. 165 (D. Alaska 1980) (there is a private right of action at least after the enactment of the 1978 amendments but no decision as to whether there was one from 1973-78); Hart v. County of Alameda, 485 F. Supp. 66 (N.D. Cal. 1979) (there is a private right of action).

154. 422 U.S. 66 (1975).

155. Id. at 78 .

156. 485 F. Supp. 66 (N.D. Cal. 1979).

157. Id. at 68

158. 611 F.2d 1074 (5th Cir. 1980).

159. Id. at 1079 . 
handicapped to the statute offered little guidance. ${ }^{160}$ That history indicates that section 504 was patterned after section 601 of the Civil Rights Act of 1964 and section 901 of the Education Amendments of 1972. ${ }^{161}$ Furthermore, the history states, "This approach to implementation of section 504, which closely follows the models of the above-cited antidiscrimination provisions, would . . . permit a judicial remedy through a private action." 162 The Hart court also noted that a private right of action has been implied under sections 601 and 901 , and that the Supreme Court in Cannon v. University of Chicago 163 "recognized that Congress, in 1973, was familiar with, and relied upon, various federal court decisions which had inferred the existence of a private right of action." 164 The court saw the 1978 amendments adding section 505 as an additional expression of legislative intent for a private right of action. ${ }^{165}$ These amendments provided that the remedies under section 504 were those under Title VI of the Civil Rights Act and that in "any action or proceeding to enforce or charge a violation of a provision of this subchapter," the court may grant attorneys' fees to the prevailing party. ${ }^{166}$

Considering section 503, the Hart court found that there was no contemporaneous evidence of an intent to create a private right of action, nor an intent to deny one. Congress, however, obviously assumed the existence of a private right of action in 1978 when it provided for attorneys' fees. ${ }^{167}$ The Hart court also noted that relaxing the legislative intent requirement is appropriate where the private right of action would enforce civil rights. ${ }^{168}$

Some courts have not found that Congress intended a private right of action under section 503. The Rogers court did not give much weight to the 1978 amendments providing attorneys' fees or to statements made at that time. Although Congress might have thought there was a private right of action in 1978, the court did not think that necessarily made it so in 1973.169 The Seventh Circuit in Simpson v. Reynolds Metals Co. ${ }^{170}$ suggested that the attorneys' fee provision in section 505 only applies to fees incurred when the individual files his complaint with the Department of Labor, ${ }^{171}$ not to fees incurred in a private action. The court was "left without any indication that, contemporaneous with its adoption of section 503, Congress intended to extend a private remedy to handicapped individuals allegedly harmed by their employer's failure to comply with his affirmative action obligation as a federal contractor."172

c. Consistent with Legislative Scheme. The Hart court decided that a private

160. 485 F. Supp. at 70.

161. S. ReP. No. 93-1297, 93d Cong., 2d Sess. 97, reprinted in 1974 U.S. Code Cong. \& AD. News 6373,6390 .

162. Id. at 106; 1974 U.S. CODE CONG. \& AD. NEwS, at 6390.

163. 441 U.S. 677 (1979).

164. Hart, 485 F. Supp. at 70.

165. Id.

166. 29 U.S.C. § 794a (1976 \& Supp. IV 1980).

167. Hart, 485 F. Supp. at 73-74.

168. 485 F. Supp. at 75 .

169. 611 F.2d at 1082 .

170. 629 F.2d 1226 (7th Cir. 1980).

171. Id. at 1242 .

172. Id. at 1243 . 
right of action for sections 503 and 504 was consistent with the underlying purpose of the statute. ${ }^{173}$ Although a plaintiff must exhaust any administrative procedures before bringing a suit, the primary administrative remedy was to terminate funding and the court believed it was "unrealistic to assume that this severe sanction [would] be freely exercised to remedy individual instances of discrimination. A private right of action, on the other hand, [could] bring about tailored, individual relief." 174 The exhaustion requirement coupled with the threat of litigation might also encourage negotiation and conciliation. ${ }^{175}$

The Fifth and Seventh Circuits have found that since section 503 itself provides an administrative remedy, a private cause of action is inconsistent with the legislative scheme. ${ }^{176}$ Furthermore, the Seventh Circuit found no proof that the administrative remedy was not sufficient. ${ }^{177}$

d. Traditionally Relegated to the States. This area has not been one traditionally within the states' powers. ${ }^{178}$

The enforcement procedures for sections 503 and 504 differ greatly. Section 503 expressly provides an administrative procedure while section 504 merely follows the procedures set out in Title VI of the Civil Rights Act. The wording of section 504 is patterned after sections 601 and 901 , under both of which a private right of action has been found. Generally, most courts have found an implied private right of action under section 504, but not under section 503 .

2. State Systems. All states which do not have administrative enforcement procedures allow complainants to proceed directly in a civil action. ${ }^{179}$ Judicial enforcement is provided by some of the states which have administrative agencies, although some states express a preference for administrative enforcement, ${ }^{180}$ and others make the initially chosen forum exclusive. ${ }^{181}$

173. 485 F. Supp. at $71,75,76$.

174. Id. at 71 .

175. Id.

176. 611 F.2d at $1083 ; 629$ F.2d at 1243 .

177. Simpson, 629 F.2d at 1244. See also Wood v. Diamond State Tel. Co., 440 F. Supp. 1003 (D. Del. 1977).

178. Hart, 485 F. Supp. at 69

179. Ga. Code ANN. §66-506 (Supp. 1981); Tex. Hum. Res. Code ANN. $§ 121.004$ (Vernon 1980); Vt. Stat. Ann. tit. 21, § 495b (Supp. 1982).

180. IOWA CODE $\S 601 \mathrm{~A} .16$ (Supp. 1981-82) (complainant must proceed with administrative remedy before initiating a court action); ME. REV. STAT. ANN. tit. 5, $\$ 4622$ (Supp. 1981-82) (providing for a limitation on damage and attorneys' fees awards for those who initiate a court action without pursuing the administrative remedy first, as well as allowing priority on the court's docket to those who have tried the administrative route before proceeding to court).

181. D.C. Code AnN. §1-2556 (1981); N.H. Rev. Stat. AnN. § 354-A:13 (Supp. 1981); N.J. Stat. ANN. § 10:5-27 (West 1976); N.Y. ExeC. LAW § 297(9) (McKinney 1982); OHIO Rev. CoDE ANN. $\S 4112.08$ (Page 1980); Pa. Stat. AnN. tit. 43, § 962(b), (c) (Purdon Supp. 1965-81); W. VA. Code $\S 5-11-$ 13 (Supp. 1982). 


\section{REMEDIES}

\section{A. Sections 503 and 504}

The several statutory remedies take many forms. As discussed above, the OFCCP and OCR have the power to terminate or suspend federal funds or contract payments. In addition, appropriate remedies may be devised for each situation. Furthermore, section 505 provides for attorneys' fees to be awarded in "any action to enforce or charge a violation of a provision of this subchapter."182

A common remedy for violation of section 503, in addition to reinstatement of the employee, is back pay. ${ }^{183}$

The 180 day time limit for filing complaints does not limit back pay awards to 180 days.

Back pay may be awarded for violations that occur up to three years prior to the filing of the complaint or notification to the contractor if the employer's violation of the statute is willful. "The Director of [the OFCCP] defines "willful" as a situation where a contractor knew or should have known that failure to take remedial action would continue the discriminatory effects.' In cases of nonwillful violations, back pay may be obtained for up to two years prior to the initial action. ${ }^{184}$

In 1977, the OFCCP published statistics on the section 503 complaints received. As of December 10, 1976, 1994 complaints involving 33 major kinds of physical and mental handicaps had been received. Of these, 204 were settled in favor of the complainant; 366 were closed because of lack of coverage; 104 were withdrawn; 180 were found not to be violations; 154 were dismissed because the complainants did not respond to government follow-up; and 29 were transferred to another agency, leaving 950 outstanding. ${ }^{185}$ Handicapped workers collected over $\$ 115,000$ in back pay as a remedy for employment discrimination. Awards ranged from $\$ 231$ to $\$ 12,000 .{ }^{186}$ The following are examples of cases in which a mentally ill worker was awarded back pay:

1. A complainant residing in the state of Virginia was awarded $\$ 2,631.12$ in back wages by an electric equipment testing company. Complainant was an applicant for the position of electronic equipment operator trainee. The company felt the complainant, whose handicap was a manic depressive personality, would be under inordinate pressure. Complainant's psychiatrist contended that the problem had remained controlled for two years with medication. Complainant accepted an alternative position with the company at the same rate of pay, plus company benefits, in addition to the back pay. ${ }^{187}$

2. An industrial equipment company awarded $\$ 1,362.34$ in back pay to a complainant residing in Texas. Because the complainant was mentally unstable, he had been demoted from the position of field salesman to a clerical position. In

182. 29 U.S.C. $\$ 794 a(b)$ (1976 \& Supp. IV 1980).

183. No information was discovered which stated expressly that a plaintiff could recover back pay under $\S 504$. However, when cases speak of damages, it is assumed that back pay is at least part of them.

184. 4 Mental Disability L. ReP. 337 (1980).

185. J. Northrup, Old Age, Handicapped and Vietnam-Era ANTIDiscrimination LegislaTION 88 (1977).

186. 1977 LAB. REL. Y.B. 363.

187. J. NORTHRUP, supra note 185 , at 92. 
addition to back wages, he was included in the company profit sharing. Complainant did not wish to be rehired. ${ }^{188}$

3. A complainant residing in Texas was awarded $\$ 419.00$ in back wages. The complainant, who suffered from emotional illness, was aware that his position would be eliminated. The company terminated him sooner than expected, however, thus eliminating a Christmas bonus. ${ }^{189}$

4. A complainant, employed by a California city as a painter, was discharged because of psychiatric problems. Upon investigation, the complainant was rehired and awarded back wages in the amount of $\$ 4,164.00 .{ }^{190}$

5. A complainant residing in Arizona, who had previously suffered mental illness, was awarded $\$ 2,916.00$ in back pay, expurgation of personnel records, and employment in a position for which he had applied, by an aircraft company. ${ }^{191}$

\section{B. State Remedies}

Whether an individual proceeds through an administrative agency or a court action, the remedies provided by statute are generally the same from state to state and resemble those of the federal system. ${ }^{192}$ The statutes provide a number of specific remedies, and also grant the hearing body latitude to impose additional or differing remedies appropriate for the particular situation. Specified remedies include: hiring, reinstatement, upgrading, admission to training programs, benefits, back pay, costs, and reasonable attorneys' fees.

With respect to damages, the statutes take varying positions. For example, Indiana restricts damages to lost wages, salaries, commissions, and fringe benefits. ${ }^{193}$ Minnesota allows not only damages for mental anguish and suffering, but also allows punitive damages not exceeding $\$ 6,000$ in cases of willful violation. ${ }^{194}$ Maine imposes an increasing scale of penal damages in which an employer pays $\$ 100$ for its first violation, $\$ 250$ for its second violation, and $\$ 1,000$ for each succeeding violation. ${ }^{195}$

Finally, certain employers may be penalized to a far greater extent than their liability to the aggrieved individual. If the business is licensed by the state, the

188. Id. at 94 .

189. Id. at 95.

190. Id. at 97.

191. Id. at 98 .

192. Conn. Gen. Stat. § 46a-82 (West Supp. 1982); D.C. Code AnN. § 1-2553 (1981); Ga. Code ANN. § 66-506 (Supp. 1981); Ill. ANN. STat. ch. 68, § 8-108 (Smith-Hurd Supp. 1982-83); IND. CodE ANN. § 22-9-1-6(k)(1) (Burns Supp. 1982); IOWA CoDE § 601A.15(8) (Supp. 1982-83); ME. REV. STAT. ANN. tit. 5, §4613(2) (1979); MD. ANN. Code art. 49B, § 11 (e) (1979); Mich. Comp. LAWS ANN. $\S$ 37.2605(2) (Supp. 1982-83); MinN. STAT. § 363.071 (2)(a) (Supp. 1981); Mont. Code ANN. § 49-2-506 (1981); Neb. Rev. Stat. § 48-1119(3) (1978); N.H. Rev. Stat. ANN. § 354-A:9(II) (1966); N.J. STAT. ANN. § 10:5-17 (West Supp. 1982-83); N.M. STat. ANN. \& 28-1-11(E) (1978); N.Y. EXEc. LAW § 297(4)(c) (McKinney 1982); OHIo Rev. Code ANn. \$\$ 4112.05(G), 4112.02(N) (Page 1980 \& Supp. 1982); PA. Stat. ANN. tit. 43, $\S \S 959,962$ (c) (Purdon Supp. 1965-81); R.I. GeN. Laws $\$ \S ~ 28-5-24,24.1$ (Supp. 1981); Tenn. Code ANn. § 8-50-103 (1980); Tex. HuM. Res. Code ANN. \$121.004 (Vernon 1980); UTAH Code ANN. § 34-35-7(12) (Supp. 1981); VT. STat. ANN. tit. 21, § 495(b) (Supp. 1982); W. VA. Code § 5-11-10 (1979); Wis. STAt. ANN. \& 111.39(4)(c) (West Supp. 1982-83).

193. Ind. Code AnN. $\$ \S 22-9-1-6(k)(1), 12.1$ (c)(8) (Burns Supp. 1982).

194. Minn. Stat. $§ 363.071$ (2) (Supp. 1981).

195. ME. Rev. Stat. ANN. tit. 5, § 4613(7) (Supp. 1981-82) 
violation may be considered by the licensing agency. ${ }^{196}$ Similarly, the state may refuse to grant the employer any public contracts for a fixed period of time following any violation of the employment discrimination statute. ${ }^{197}$

\section{VI}

\section{CONCLUSION}

The 1970's witnessed unprecedented federal and state legislative concern for the difficulties faced by mentally ill persons who seek to become integrated members of the working world. Of course this concern and its statutory evidence did not appear suddenly. They were the product of a long-developing trend rooted in the improved therapeutic techniques which have enabled substantial numbers of mentally ill persons to function in ways that would previously have been prevented by their sickness.

It is one thing to recognize significant legislative efforts to fashion laws prohibiting illogical and invidious discrimination against mentally ill persons, and it is quite another to evaluate the utility of such legislation in the absence of case law interpreting and applying the statutes. An explanation of why so few employment cases have been litigated on behalf of the mentally ill would provide excellent clues in the quest to discover how this long-downtrodden group has fared in the labor market. However, an attempt to uncover the reason why so few public interest lawyers have taken up the banner of the mentally ill in the employment realm necessitates the construction of a double-helix chain of causation more complex than DNA itself. Suffice it to say that legislation is now in place which illustrates concern for the mentally ill beyond the treatment setting. Legal practitioners, mental health administrators, and therapists must now work together to breathe life into the mental health employment legislation, and make the lofty goals, hopes, and dreams embodied in the legislation become a reality.

196. D.C. Code ANN. $\S 1-2557$ (1981); Ill. ANN. Stat. ch. 68, § 8-109(B) (Smith-Hurd Supp. $1982-$ 83); Iowa Code $\S 601$ A.15(8)(b)(1) (Supp. 1981); Minn. Stat. § 363.071(4) (Supp. 1981); Pa. Stat. AnN. tit. 43, § 959 (Purdon Supp. 1965-81).

197. Ill. ANN. STAT. ch. 68, § 8-109(A) (Smith-Hurd Supp. 1982-83); Iowa CoDE § 601A.15(b)(2)(3) (Supp. 1981); MinN. StaT. $\$ 363.071(5)$ (Supp. 1981). 
